\title{
Mesucalophylloidin, a new isoprenylated 4-phenylcoumarin from Mesua calophylloides (Ridl.) Kosterm
}

\author{
Mulyadi Tanjung ${ }^{a}$, Fida Rachmadiarti ${ }^{b}$, Ratih Dewi Saputria and Tjitjik Srie Tjahjandarie ${ }^{a}$ \\ aNatural Products Chemistry Research Group, Organic Chemistry Division, Faculty of Science and Technology,

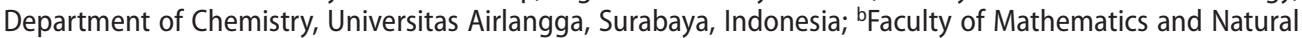 \\ Sciences, Department of Biology, Universitas Negeri Surabaya, Surabaya, Indonesia
}

\begin{abstract}
A new isoprenylated 4-phenylcoumarin derivative, mesucalophylloidin (1) along with three known compounds, mammea A/BA cyclo F (2), calolongic acid (3) and isocalolongic acid (4) were isolated from the stem bark of Mesua calophylloides (Ridl.) Kosterm. Structures of all the compounds were elucidated using extensive spectroscopic methods, including UV, IR, HRESIMS, 1D and 2D NMR. Compounds 1-4 were evaluated for their cytotoxicity against P-388 cells, showing that compound 1 gave moderate activity with $\mathrm{IC}_{50} 6.26 \mu \mathrm{g} / \mathrm{mL}$.
\end{abstract}

\section{ARTICLE HISTORY}

Received 1 July 2017

Accepted 22 August 2017

\section{KEYWORDS}

Mesucalophylloidin; isoprenylated 4-phenylcoumarin; Mesua calophylloides; P-388 cell

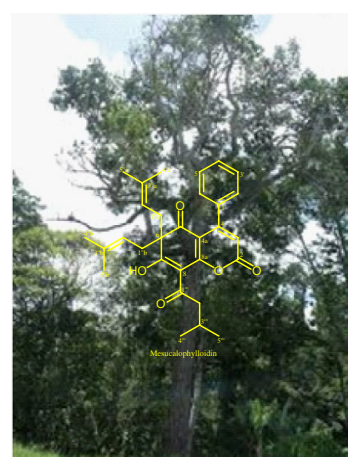

\section{Introduction}

Mesua calophylloides (Ridl.) Kosterm. locally known 'bitangur kunyit' with a commercial name ironwood belongs to the Clusiaceae family. This species of Mesua is endemic in Kalimantan Island and East Malaysia. Based on ethnomedicinal, the decoction of stem bark or leaves this plant has been used in the Dayak people to treat some diseases (Heyne 1987). The phytochemical survey from this plant until now has been not reported. The Mesua genus has been shown to be prolific a number of secondary metabolites, particularly xanthones (Singh et al. 1993; Karunakaran et al. 2016), coumarins (Awang et al. 2010; Rouger et al. 2015; Tanjung 